\title{
Traceability System as Perceived-Uncertainty Mitigator for Sustainable Global Food Trade
}

DOI: 10.12776/QIP.V20I1.625

\author{
Renee B. Kim, Qiao Zhang, Dong Hyun Yoon \\ Received: 2015-10-19, Revised 10 April 2016, Accepted 27 May 2016
}

\begin{abstract}
Purpose: The paper validates a model which approximates a relationship between perceived uncertainty of consumers and two antecedents \& three mitigators which explain the value of Food Traceability System (FTS).

Methodology/Approach: The proposed model was drawn from Pavlou et al. (2007) study which applied the principal-agent perspectives, and this study contributes to current literature by improving understanding of structure of perceived uncertainty of a food product with credence good with this model.
\end{abstract}

Findings: The study assesses the value and effects of FTS in reducing perceived uncertainty of beef from various origins and suggests important implications for stakeholders in beef sector regarding feasibility and marketability of FTS.

Research Limitation/implication: Findings evidently reflect the current market circumstance regarding consumers' concerns and Perceived Uncertainty towards import food products for their credence nature. Different aspects of FTS were found to have mediating role in reducing Perceived Uncertainty in China and South Korea.

Originality/Value of paper: The study assesses the value and effects of FTS in reducing perceived uncertainty of beef from various origins and suggests important implications for stakeholders in beef sector regarding feasibility and marketability of FTS.

Category: Research paper

Keywords: Perceived Uncertainty; Food Traceability System (FTS); consumer behavior; Sustainable Global Food Trade 


\section{INTRODUCTION}

Various types of food scares associated with food safety impact consumers' attitude towards food choices and consumption substantially, and consumer concern for food safety appear at the forefront of competitiveness of the agrifood industry. Consumers' demand for adequate information on quality and safety of food products are increasing as they prefer to make an informed choice. Nonetheless, inherently sellers have more information on the quality and safety of products and consumers often have limited access to product information which leads to increased perceived risk. In particular, food safety is credence good which consumers are unable to assess without seller's assistance or additional information.

Furthermore, increase in agri-food trade due to rise in free trade agreement (FTA) among nations, brought broader availability of foreign food products in consumers' choice set, and consumers are faced with heightened uncertainty in the origin and safety of import food products. Consequently, country of origin has become one of the key attributes which are used by consumers in purchasing imported products. Country of origin effects refers to the extent to which a product's evaluation is affected by its place of manufacture (Gurhan-Candli and Maheswaran 2000). Country of origin is considered to be an attribute with significant impact on consumers' choice behavior of foreign products and various studies reported on this finding (Nagashima, 1970; Hong and Wyer, 1989; Maheswaran 1994; Häubl 1996; Aboulnasr, 2006). Consumers' evaluation of products is often based on country of origin stereotypes, thus the way consumers acquire, process and use the country of origin information may also have important effect on consumers' choice behavior.

In order to facilitate food transactions in the supply chain, and to reduce consumers' perceived risk in food choice, countries recently introduce Food Traceability System (FTS) which trace all relevant information on food process from farm to end-user point, including country of origin information. When consumers can recognize the country origin of a product with an aid of FTS, they can make informed diagnosis of the quality \& safety of the products. Food Traceability System (FTS) which function as a vehicle to provide more information on the product quality and safety to consumers may facilitate them to evaluate product quality based on information from FTS instead of their prior biases or expectation of products. The more diagnostic an attribute, the more helpful this attribute is for consumers in evaluating the quality and performance of a product (Jiang and Benbasat, 2004). In other words, more diagnostic information is more likely to be used as an input for evaluative judgment than information that is ambiguous or non-diagnostic (Garretson and Burton, 2000; Aboulnasr, 2006). Thus, consumers appear to rely more on the information rather than their prior expectation when they are presented with unambiguous quality information (Jiang and Benbasat 2004; Garreston and Burton, 2000; Kempf and Smith, 1998; Aaker, 2000). Furthermore, this facilitates food transaction in the market by reducing consumers' perceived uncertainty of product quality and 
safety. Ultimately improved efficiency in the market transaction may be reflected in consumers' willingness to pay price premium for certain country origin and to purchase larger quality.

\section{TRACEABILITY SYSTEM IN CHINA AND SOUTH KOREA}

Among several types of food products, beef is chosen as this is an item which has been drawing international attention regarding food safety, free trade agreement (FTA) talks as well as local producers and consumers' reluctance in accepting import beef. Several outbreaks of Bovine spongiform encephalopathy (BSE) in various countries in the past have increased consumers' concerns and perceived risk of food safety of beef, causing significant negative impact on beef products from specific country of origin. Food safety is a credence attribute (i.e.consumers cannot assess the food safety level even after they consume), thus consumers tend to rely on other intrinsic and extrinsic cues (i.e. country origin) to infer food safety. As a consequent, the beef industry has introduced a Food Traceability System (FTS) and strengthened vertical coordination in the food supply chain to enhance food safety. FTS is an extrinsic cue which certifies the quality and safety of beef products by transforming food safety from credence attribute to a search attribute.

FTS has been adopted by many advanced economies such as Japan, France, Australia and the U.S. Japan initiated its beef traceability system in 1999 and set up a database management system in 2002 and completed implementation of beef traceability system in 2003 at production level, and in 2004 expanded the FTS to distribution level. The U.S. introduced a plan for traceability system in 2002 and developed database management system in 2004 and completed the farm \& cattle registration in 2008. We selected China and South Korea as target markets for beef transactions at consumer level to empirically test the impact of FTS, and to assess the effect of antecedents on consumer's perceived uncertainty and purchase intension. These two markets are chosen since these are two major beef trading countries in Asia and beef products from different country of origin prevalently exist in their consumer markets. Upon the outbreak of Canada's first BSE-infected cow in Alberta in May 2003, which was transferred to the U.S., several beef import countries in Asia banned U.S. beef and cattle products, including China, South Korea, Taiwan, Hong Kong etc. This had tremendous negative impact on beef export countries such as the U.S. and Canada, resulting in substantial gross farm income loss in these countries (i.e. $20 \%$ of gross farm income in the U.S declined due to this ban).

Upon the completion of U.S-Korea FTA in 2008, South Korean beef market officially open access to U.S. beef in 2008, nonetheless the Korean consumers were considerably concerned with food safety of U.S. beef. In order to strengthen food risk management and respond to consumers concern, the Korean government operated pilot test of BSE in 2004, and officially activated FTS on beef sector in 2007. The FTS on beef production level started in 2008 and the 
FTS on distribution level started in 2009. Since 2010, the public trust of Korean beef safety and quality increased significantly, and Korean beef market share increased from $43.2 \%$ in 2010 to $50.3 \%$ in 2013. Currently, there are five types of beef, differentiated by country of origin, including Korea, the U.S., Australia, Canada and New Zealand. Korean consumers' preference for import beef still remains to be considerably lower than that of domestic beef due to perceived uncertainty regarding food safety.

On the other hand, China continues to increase its beef imports in recent years and food safety and quality of import beef has become an important issue. China is the world's largest meat consuming country and its beef import is forecasted to double by 2018 as domestic output fails to meet demand. Chinese per capita beef consumption is $4.5 \mathrm{~kg}$ in 2013 (weights on a carcass-weight basis), which is expected to grow to $6 \mathrm{~kg}$ by 2020, getting close to the world average of $8.1 \mathrm{~kg}$. Various food scare outbreaks in China heightened consumer concerns for food safety and it is one of the most contending current social issues in China. Due to cope with this challenge, the Chinese government and the industry are in discussion to implement FTS. In China's private sector, HACCP, GAP and other international safety certification standards are increasingly adopted by the private firms on a voluntary basis, while Quality Safety (QS) is the only officially implemented safety certification on a mandatory basis. By 2005, 2,846 food companies in China have implemented HACCP certification (Wang et al., 2006), and the number of food processing firms in China continues to increase and officially registered companies were estimated to be 19,022 in 2003 , thus the proportion of Chinese food companies with HACCP certification remains relatively low. This may primarily be due to the fact that introduction of HACCP based systems may be difficult in small and medium sized food businesses with limited capacity and knowledge (Kim et al., n.d.).

In addition, China decided to apply GS1's GTS in order to facilitate its trade with European and other major trading partner countries. As a pilot project, one of Chinese private food manufacturing firm-Synbroad Ltd. adopted GTS by GS1 China, and successfully maintained market position in Europe. With this application of traceability system, Synbroad Ltd. gained the following competitive advantages: compliance with the international traceability standards; automation of all operational traceability process in the companies; strengthening Synbroad competitive compliancy with the European Food Law (GS1, 2009). However, GS1 China also faces with considerable challenges; training and learning on GS1 standards by relevant stakeholders; identifying equipment to support the data flow exchanged; and allocation/assignment of specific tasks involved in the GTS process. For successful adoption of such system, GS1 China identified critical success factors such as sufficient funding supports, high level sponsorship and leadership from both company management and government and effective communication of all relevant actors in the system (Kim et al., 2015). This implies that ultimately the system has been to recognized and supported by the end-users (i.e. Consumers) in order to justify associated costs 
and investments. Therefore, it is imperative to conduct a comprehensive study on whether the FTS is perceived to be valuable in the eyes of consumers. From exporters and marketers perspectives, findings provide worthwhile guideline in determining feasibility of Food Traceability System (FTS) in their food supply chains.

The purpose of this paper is to determine whether Food Traceability System (FTS) affect consumers' choice behavior of beef products from various country of origin. More specifically, the study attempt to verify the positive effects of FTS on consumers' purchase decision of beef products by mitigating the perceived uncertainty of consumers towards beef products from various countries. This study adopts Pavlou, Liang and Xue (2007) model which approximate the relationship between perceived uncertainty and purchase intention of consumers. In addition, findings from this study provide practical implications for stakeholders in beef supply chain, regarding return on investments of FTS in beef sector and value-adding potentials of FTS. In other words, the proposed model attempts to examine whether consumers from China and South Korea perceive FTS to an additional value in their purchasing decision process.

\section{CONCEPTUAL FRAMEWORK}

Choe et al. (2009) state that the perceived risk of consumers stems from uncertainty due to lack of declarative knowledge, or insufficient knowledge of the outcome of the consumption act. Perceived uncertainty refers to the degree by which the outcome of a transaction cannot be accurately predicted, the future sales of the transaction could vary from a successful product fulfillment to any combination of the numerous adverse possibilities (Pavlou, Liang and Xue, 2007). Individual consumers inherently have limited access to the quality and safety of products, and are faced with numerous adverse possibilities, they tend to overestimate the probability of potential losses, even if the probabilities of such losses is low (Kahneman and Tversky, 1979). Uncertainty perceptions give rise to perception of risk (Chiles and McMackin, 1996). In other words, the perceived uncertainty of product quality and safety is the sole source of perceived risk of consumers. Based on this assumption, we propose that FTS decrease perceived uncertainty by providing sufficient information on product quality, and ultimately have positive effect on consumers' choice behavior.

Pavlou, Liang and Xue (2007) apply the principal-agent perspective in developing their conceptual framework for consumers' choice behavior in an ecommerce adoption setting. Their model explicitly addresses the source of uncertainty with this approach. The principal-agent perspective virtually applies to all transactional exchanges that occur in a socio-economic system of opportunism, asymmetric information, and bounded rationality (Milgrom and Roberts, 1992). Since food transaction situation involves high degree of 
uncertainty, this framework is considered to be appropriate to approximate consumers' food choice behavior.

\section{Antecedents of Perceived Uncertainty: Information Asymmetry \& Fear of Seller Opportunism}

The principal-agent perspective addresses an agent relationship in which one entity (the principal) delegates work to another (the agent) who performs the work according to a mutually agreed contract (Esenhardt, 1989). Agency relationships are instituted whenever one party depends on another party to undertake some action on its behalf (Jensen and Meckling, 1976). Due to asymmetric information provided to the principal and the agent, it naturally raises an issue of agency problems of hidden information and hidden action (i.e. misrepresentation of seller quality and of product quality). Thus, hidden information poses difficulty to the buyer in terms of selecting a true high quality seller and products.

Pavlou, Liang and Xue (2007) identify perceived information asymmetry and fears of seller opportunism as main sources of perceived uncertainty. Perceived information asymmetry exists as buyers perceive sellers to have a greater quantity or quality of information than they do. Information asymmetry makes it difficult for buyers to assess the sellers' true characteristics and product quality, resulting in higher perceived uncertainty. In addition, buyers may assume hidden action of sellers as they act opportunistically to serve their self-interest given difference of interests (Pavlou, Liang and Xue, 2007). An example of seller opportunism includes quality cheating, masquerading true identity, contract default, or not acknowledging product warranties (Mishra, Heide and Cort, 1998). These types of hidden action increase perceived uncertainty of buyers. The two identified antecedents are hypothesized to have a positive effect on consumers' perceived uncertainty of products within the framework of the principal-agent perspective, thus the agency problem of hidden information and hidden action are claimed to be mitigated through change in buyers' beliefs (i.e. trust, informativeness and product diagnosticity).

\section{Uncertainty Mitigators: Product Diagnosticity, Informativeness \& Trust}

Product diagnosticity refers to the ability to convey relevant product information to help buyers accurately evaluate product quality (Pavlou and Fygenson, 2006). FTS may enable sellers to convey information about the true quality of their product, enabling consumers to assess product quality and safety adequately. Increased perceived diagnosticity allows consumers to feel more informed about products, which leads to informed purchased decisions (Jiang and Benbasat, 2004). As a result, product diagnosticity mitigates a buyers' perceived information asymmetry. Informativeness in the FTS is defined as the extent to which the information provided to consumers is actually helpful (Choe et al. 
2009). Since there can be various types of information which can be provided, seller needs to decide information which are cost-efficient and relevant to consumers' concern and interest. Informativeness address the importance of the quality and relativity of information provided to consumers. When consumers believe that they are provided with helpful and reliable information, their perceived information asymmetry and fear of seller opportunism are likely to be reduced. Trust is a psychological state that is most valuable under-conditions of uncertainty (Mayer, Davis and Schoorman, 1995), and the intention of the buyer to accept the vulnerability of transaction, believing that the seller will not act opportunistically (Pavlou and Gefen, 2004; Rousseau et al., 1998). Thus, trust mitigate fears of seller opportunism and information asymmetry, as buyers carry on their transaction based on their trust for seller's competence, integrity, facilitating buyer-seller relationships (Swan and Nolan, 1985).

Figures (1-4) show the overall model of FTS impact on consumers' choice behavior and the path relationship of selected constructs. Purchase intention is set as the dependent variable, reflecting consumers' acceptance of FTS. Perceived information asymmetry and fears of seller opportunism are selected two antecedents, affecting perceived uncertainty of consumers which ultimately result in their purchase intention. Three mitigators: product diagnosticity, informativeness and trust are proposed to reduce the impact of two antecedents with an assistance of FTS (Table 1).

Table 1 - Definition of Constructs

\begin{tabular}{ll}
\hline Constructs & \multicolumn{1}{c}{ Definition } \\
\hline Product Diagnosticity & $\begin{array}{l}\text { The extent to which a buyer believes that a particular shopping } \\
\text { experience is helpful in terms of evaluating the quality and } \\
\text { performance of a product (Kempf and Smith 1998) }\end{array}$ \\
Informativeness & $\begin{array}{l}\text { The extent to which seller provides users with resourceful and } \\
\text { helpful information (Ducoffe, 1995) }\end{array}$ \\
Trust & $\begin{array}{l}\text { Intention of the buyer to accept the vulnerability of the transaction, } \\
\text { believing that the seller will not act opportunistically (Pavlou and } \\
\text { Gefen, 2004) }\end{array}$
\end{tabular}

Information Asymmetry The difference between the information that buyers and sellers possess.

Fears of Seller

Opportunism

The buyer's concerns that the seller may act opportunistically (Pavlou and Fygenson, 2006)

Perceived Uncertainty The degree to which the outcome of a transaction cannot be accurately predicted, (Pavlou and Fygenson, 2006) 


\section{RESEARCH METHOD: CROSS-COUNTRY VALIDATION OF FOUR PROPOSED MODELS}

\section{Survey Sampling \& Data Analysis}

The survey questionnaire was designed and developed based on measures which were defined in Pavlou, Liang and Xue (2007) study and the items of the survey questionnaire are listed in Table 1. All items were measured with five-point Likert-type scales.

The structural model has three constructs which were defined as uncertainty mitigators: Product Diagnosticity, Informativeness \& Trust; two constructs, identified as uncertainty sources: Perceived Information Asymmetry \& Fears of Seller Opportunism; and one construct as a dependent variable, Purchase Intention. In total, 26 items were measured to assess the proposed model (Table 2).

Table 2 - Measurement Items for the Structural Model

\begin{tabular}{|c|c|c|c|}
\hline Constructs & $\begin{array}{l}\text { Item } \\
\text { No. }\end{array}$ & $\begin{array}{c}\text { \# of } \\
\text { Items }\end{array}$ & Measurement Items \\
\hline Product Diagnosticity & $\begin{array}{l}\text { Item } 1 \\
\text { Item } 2 \\
\\
\text { Item } 3\end{array}$ & 3 & $\begin{array}{l}\text { I expect the traceability system to help me carefully } \\
\text { evaluate beef products. } \\
\text { Being able to carefully evaluate beef products } \\
\text { would make it much easier for me to purchase beef } \\
\text { products. } \\
\text { I expect the traceability system to help me get a real } \\
\text { feel for beef products. }\end{array}$ \\
\hline $\begin{array}{l}\text { Informative } \\
\text { ness }\end{array}$ & $\begin{array}{l}\text { Item } 4 \\
\text { Item } 5\end{array}$ & 2 & $\begin{array}{l}\text { A traceability system would give me quick and easy } \\
\text { access to large volumes of information. } \\
\text { I would learn a lot from using a traceability system. }\end{array}$ \\
\hline Trust & $\begin{array}{l}\text { Item } 6 \\
\text { Item } 7 \\
\text { Item } 8\end{array}$ & 3 & $\begin{array}{l}\text { The traceability system provides objective } \\
\text { information on beef products sufficiently. } \\
\text { Information provided by the traceability system is } \\
\text { trustworthy. } \\
\text { I expect the traceability system to provide accurate } \\
\text { information trustfully. }\end{array}$ \\
\hline $\begin{array}{l}\text { Perceived Information } \\
\text { Asymmetry }\end{array}$ & $\begin{array}{l}\text { Item } 9 \\
\text { Item } 10\end{array}$ & 2 & $\begin{array}{l}\text { The traceability system reduces the information gap } \\
\text { on the "quality of beef products" between the } \\
\text { producers and the consumers. } \\
\text { The traceability system reduces the information gap } \\
\text { on the "circulation process of beef products" } \\
\text { between the producers and the consumers. }\end{array}$ \\
\hline $\begin{array}{l}\text { Fears of Seller } \\
\text { Opportunism }\end{array}$ & $\begin{array}{l}\text { Item } 11 \\
\text { Item } 12 \\
\text { Item } 13\end{array}$ & 3 & $\begin{array}{l}\text { The producers of beef products who sell through the } \\
\text { traceability system will not cheat on consumers. } \\
\text { The sellers of beef products who sell through the } \\
\text { traceability system will not counterfeit the period of } \\
\text { circulation } \\
\text { The traceability system will reduce the possibility of } \\
\text { illegal production. }\end{array}$ \\
\hline
\end{tabular}




\begin{tabular}{|c|c|c|c|}
\hline Constructs & $\begin{array}{l}\text { Item } \\
\text { No. }\end{array}$ & $\begin{array}{c}\text { \# of } \\
\text { Items }\end{array}$ & Measurement Items \\
\hline $\begin{array}{l}\text { Perceived Uncertainty } \\
\text { (Domestic \& } \\
\text { Imported) }\end{array}$ & $\begin{array}{l}\text { Item } 14 \\
\text { Item } 15 \\
\text { Item } 16\end{array}$ & 4 & $\begin{array}{l}\text { Purchasing domestic beef products through the } \\
\text { traceability system will decrease the degree of } \\
\text { uncertainty associated with the products. } \\
\text { Purchasing imported beef products through the } \\
\text { traceability system will decrease the degree of } \\
\text { uncertainty associated with the products. } \\
\text { Purchasing domestic beef products through the } \\
\text { traceability system will decrease the degree of } \\
\text { uncertainty that occurs as a post-purchasing } \\
\text { reaction. } \\
\text { Purchasing imported beef products through the } \\
\text { traceability system will decrease the degree of } \\
\text { uncertainty that occurs as a post-purchasing } \\
\text { reaction. }\end{array}$ \\
\hline $\begin{array}{l}\text { Purchase intention } \\
\text { (Domestic \& } \\
\text { Imported) }\end{array}$ & $\begin{array}{l}\text { Item } 18 \\
\text { Item } 19 \\
\text { Item } 20 \\
\text { Item } 21 \\
\text { Item } 22\end{array}$ & 9 & $\begin{array}{l}\text { I plan to continue purchasing domestic beef } \\
\text { products using the traceability system } \\
\text { I plan to continue purchasing imported beef } \\
\text { products using the traceability system } \\
\text { I intend to increase the size of domestic beef } \\
\text { products purchases using the traceability system. } \\
\text { I intend to increase the size of imported beef } \\
\text { products purchases using the traceability system. } \\
\text { I intend to increase the frequency of purchasing } \\
\text { domestic beef products using the traceability } \\
\text { system. } \\
\text { I intend to increase the frequency of purchasing } \\
\text { imported beef products using the traceability } \\
\text { system. } \\
\text { How much more are you willing to pay for domestic } \\
\text { beef products through traceability systems? } \\
\text { How much more are you willing to pay for imported } \\
\text { beef products through traceability systems? } \\
\text { Please select which country's beef products do you } \\
\text { prefer? (China, USA, Australia, Canada, New } \\
\text { Zealand) }\end{array}$ \\
\hline
\end{tabular}

Local Marketing Agencies in South Korea and China administered data collection of the survey. The proposed model was empirically tested with survey data from 350 Chinese Consumers and 305 Korean consumers. Chinese survey was done in two major cities in China (i.e. Beijing and Shanghai), while Korean survey was done in various cities in South Korea (Table $3 \& 4$ ). The sample in China was $76.6 \%$ male and $23.4 \%$ female; $93 \%$ of respondents were younger than 40 ; respondents tend to have high education level; $43.8 \%$ of respondents were students, $50 \%$ of respondents had professional occupations. $43 \%$ of Chinese respondents earn monthly income less than $3000 \mathrm{RMB}, 42 \%$ of them earn between 3000-10,000 RMB per month. The sample in South Korea was 63.5\% male and $36.5 \%$ female; $41.8 \%$ of them are between $30-39$ years old, $26.2 \%$ are 
in 20 s and $26.7 \%$ are in $40 \mathrm{~s} ; 58.7 \%$ of the respondents had college education; $30.2 \%$ of the respondents make 30.2 Million KW (MKW) per year, 26.2\% make 20-30 MKW. Structural equation modeling was used to analyze the collected data with AMOS 18.0.

Table 3 - Demographic Profile of Chinese Respondents

\begin{tabular}{|c|c|c|c|c|}
\hline Variable & Section & $\begin{array}{c}\text { No. of } \\
\text { Frequency }\end{array}$ & $\begin{array}{c}\text { Valid Percent } \\
(\%)\end{array}$ & Total \\
\hline \multirow{2}{*}{ Gender } & Male & 229 & 76.6 & \multirow{21}{*}{299} \\
\hline & Female & 70 & 23.4 & \\
\hline \multirow{5}{*}{ Age } & Under 20 years old & 4 & 1.3 & \\
\hline & 20 30 years old & 210 & 70.2 & \\
\hline & 30 40 years old & 69 & 23.1 & \\
\hline & 40 50 years old & 12 & 4.0 & \\
\hline & 50 years of age or older & 4 & 1.3 & \\
\hline \multirow{4}{*}{ Education } & College Student/Graduated & 2 & 7.0 & \\
\hline & University Student & 26 & 8.7 & \\
\hline & Bachelor's Degree & 60 & 20.1 & \\
\hline & $\begin{array}{l}\text { Master Degree/A higher } \\
\text { Degree }\end{array}$ & 211 & 70.6 & \\
\hline \multirow{5}{*}{ Job } & Student & 131 & 43.8 & \\
\hline & $\begin{array}{l}\text { Normal/Government } \\
\text { Employee }\end{array}$ & 85 & 28.4 & \\
\hline & $\begin{array}{l}\text { Specialized Job } \\
\text { (Medical Doctor, Lawyer, } \\
\text { Teacher or others) }\end{array}$ & 66 & 22.1 & \\
\hline & Freelancers(Merchant) & 6 & 2.0 & \\
\hline & Others & 11 & 3.7 & \\
\hline \multirow{5}{*}{$\begin{array}{l}\text { Income } \\
\text { (month) }\end{array}$} & $<3,000(\mathrm{RMB})$ & 129 & 43.1 & \\
\hline & $3,000 \sim 5,000(\mathrm{RMB})$ & 64 & 21.4 & \\
\hline & $5,000 \sim 10,000(\mathrm{RMB})$ & 63 & 21.1 & \\
\hline & $10,000 \sim 20,000(\mathrm{RMB})$ & 33 & 11.0 & \\
\hline & $>20,000(\mathrm{RMB})$ & 10 & 3.3 & \\
\hline
\end{tabular}


Table 4 - Demographic Profile of Korean Respondents

\begin{tabular}{|c|c|c|c|c|}
\hline Variable & Section & $\begin{array}{c}\text { No. of } \\
\text { Frequency }\end{array}$ & $\begin{array}{c}\text { Valid Percent } \\
(\%)\end{array}$ & Total \\
\hline \multirow{2}{*}{ Gender } & Male & 143 & 63.5 & \\
\hline & Female & 82 & 36.5 & \\
\hline \multirow{4}{*}{ Age } & 20 29 years old & 59 & 26.2 & \\
\hline & 30 39 years old & 94 & 41.8 & \\
\hline & 40 49 years old & 60 & 26.7 & \\
\hline & 50 years of age or older & 12 & 5.3 & \\
\hline \multirow{4}{*}{ Education } & High school graduate & 40 & 17.8 & \\
\hline & College student & 43 & 19.1 & 225 \\
\hline & Bachelor's Degree & 132 & 58.7 & \\
\hline & Master Degree or higher & 10 & 4.4 & \\
\hline \multirow{5}{*}{$\begin{array}{l}\text { Income } \\
\text { (million } \\
\text { won/year) }\end{array}$} & $<20(\mathrm{KRW})$ & 68 & 30.2 & \\
\hline & $20 \sim 30(\mathrm{KRW})$ & 59 & 26.2 & \\
\hline & $30 \sim 40(\mathrm{KRW})$ & 40 & 17.8 & \\
\hline & $40 \sim 50(\mathrm{KRW})$ & 24 & 10.7 & \\
\hline & $>50(\mathrm{KRW})$ & 34 & 15.1 & \\
\hline
\end{tabular}

\section{Development of Four Models}

Figures (1-4) are the proposed models which are estimated with survey data to determine the antecedents explaining perceived uncertainty of consumers for beef safety and consumers' purchase intention of beef from various country origins. Empirical data analysis enable discovery of three aspects: two antecedents of perceived uncertainty of consumers for beef; the effects of FTS (through three factors) on the identified antecedents; the impact of FTS on consumers' purchase intention of beef products, 


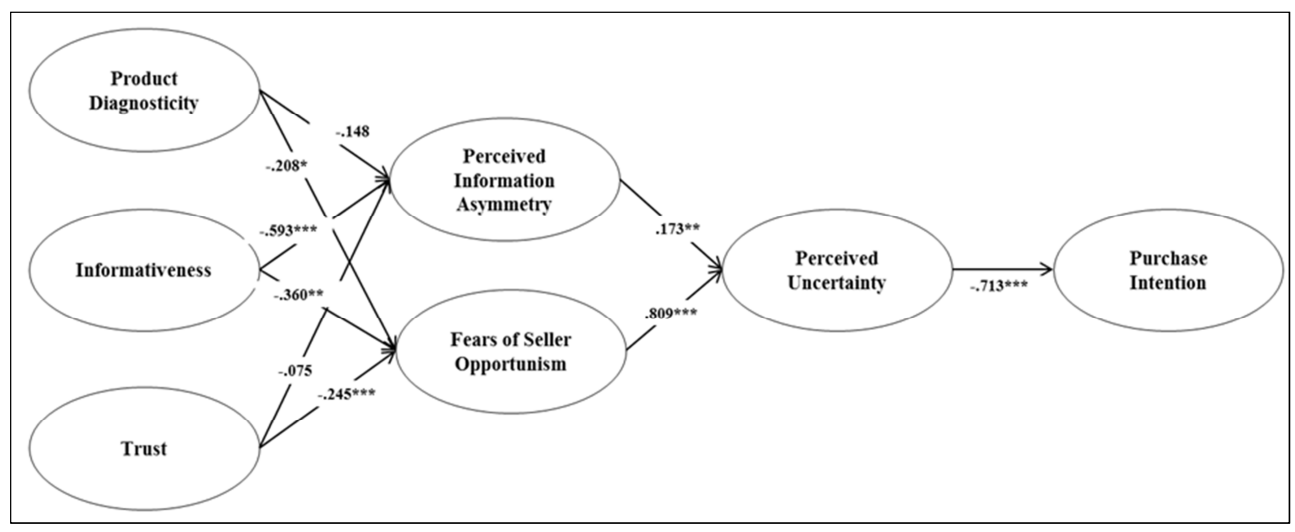

Figure 1 - The China Domestic Model: Effect of FTS on Perceived Uncertainty \& Purchase Intention

In order to determine the differentiated effects of FTS on consumers' beef purchase intention from domestic vs. import origin, separate models were developed for consumers' purchase intention for domestic beef vs. import beef. Due to Chinese and Korean consumers' negative reaction to recent BSE outbreaks in major beef exporting countries, it is important to assess how they value the FTS differently on domestic and import beef purchase situations. Consequently, four separate models were developed for China and South Korea: the China Domestic Model, the China Import Model, the Korea Domestic Model; and the Korea Import Model.

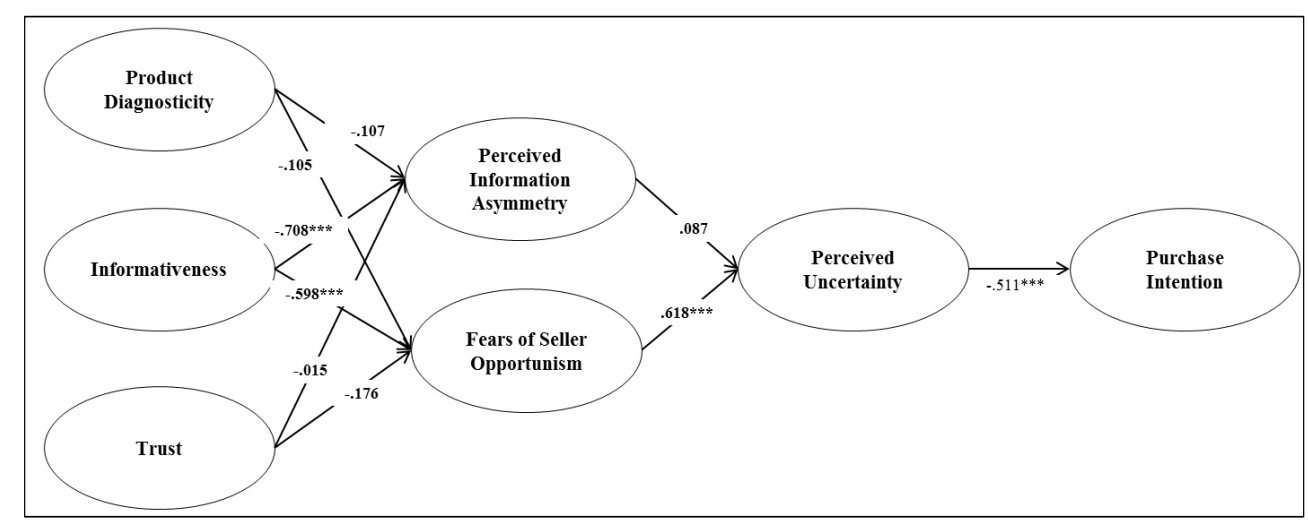

Figure 2 - The China Import Model: Effect of FTS on Perceived Uncertainty \& Purchase Intention 


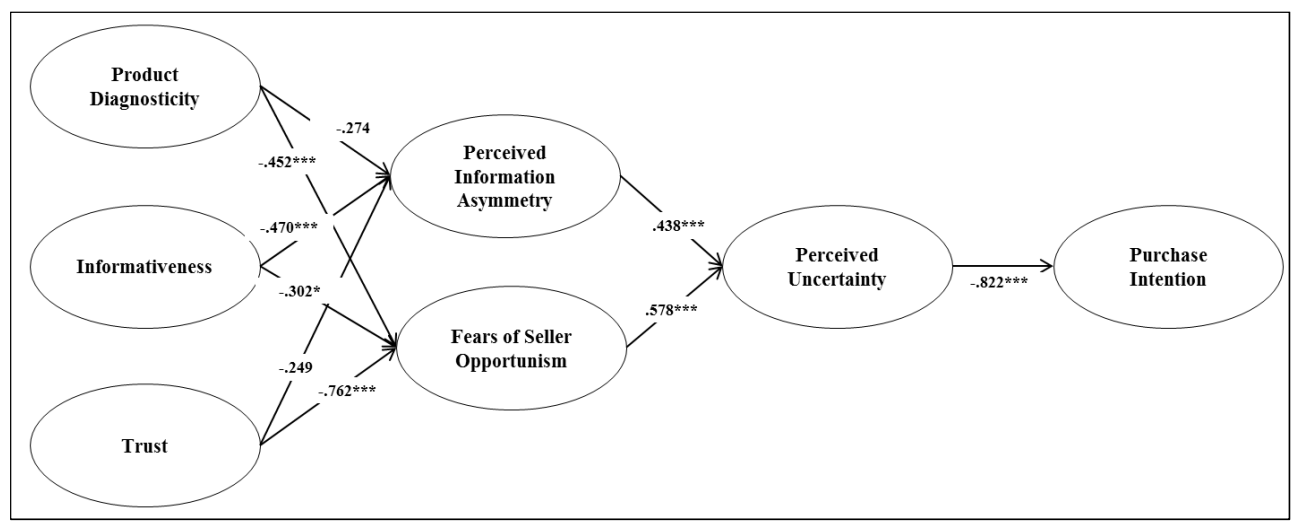

Figure 3 - The Korea Domestic Model: Effect of FTS on Perceived Uncertainty \& Purchase Intention

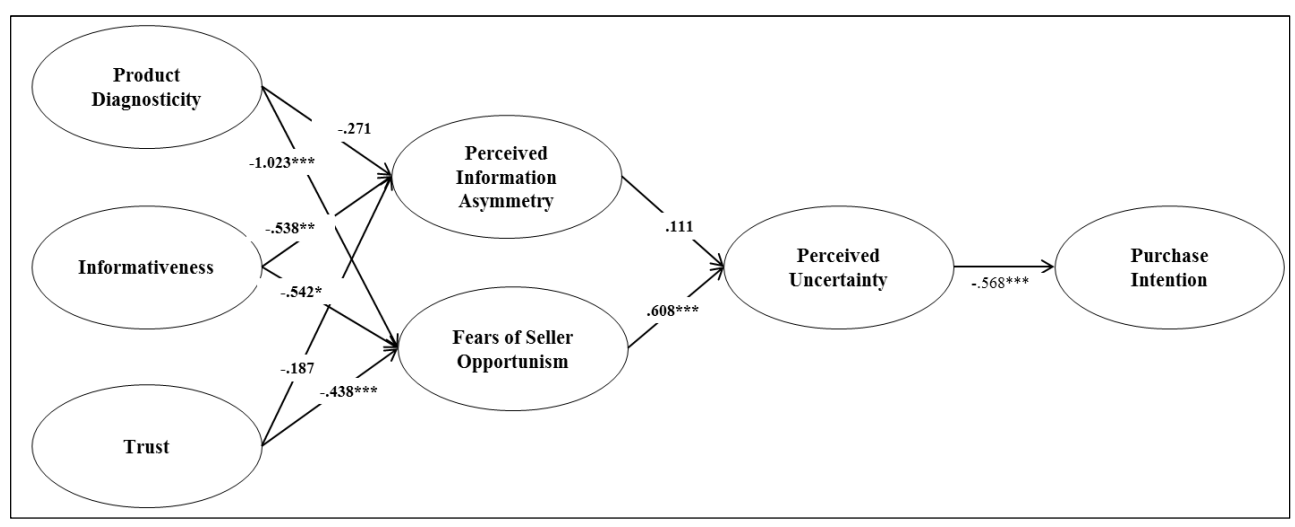

Figure 4 - The Korea Import Model: Effect of FTS on Perceived Uncertainty \& Purchase Intention

\section{ANALYSIS AND RESULTS}

An exploratory factor analysis (EFA) was executed by maximum likelihood extraction method, with varimax rotation to determine the number of factors, followed by confirmatory factory analysis (CFA). Cronbach's coefficient alpha $(\alpha)$ was calculated to assess the internal reliability of the six dimensions affecting consumers' beef purchase intention and to select the final items of the model. The estimated results were found to be satisfactory with most of the alpha values higher than 0.7. This indicates satisfactory levels of internal consistency (Table 5). 
Table 5 - Reliability Analysis: China \& Korea

\begin{tabular}{lcc}
\hline \multirow{1}{*}{ Construct } & China & Korea \\
\cline { 2 - 3 } & Cronbach's Alpha & Cronbach's Alpha \\
\hline Product Diagnosticity & .642 & .647 \\
Informativeness & .556 & .656 \\
Trust & .829 & .733 \\
Perceived Information & .789 & .650 \\
Asymmetry & & \\
Fears of Seller Opportunism & .713 & .756 \\
Perceived Uncertainty(domestic) & .817 & .710 \\
Perceived Uncertainty(import) & .887 & .762 \\
Purchase Intention(domestic) & .560 & .729 \\
Purchase Intention(import) & .680 & .763 \\
\hline
\end{tabular}

Convergent validity was assessed by determining whether each observed variable's estimated maximum likelihood factor loading on its latent construct was significant (Anderson \& Gerbing, 1988). Table 6 indicate that most items' loadings on their corresponding construct (i.e. path coefficients) were significant at $\mathrm{p}<.05$, demonstrating adequate convergent validity. Factor loadings in the model had a reasonable range both for China and Korea models (Table 6).

Table 6 - Confirmatory Factor Analysis: China \& Korea

\begin{tabular}{lccc}
\hline Factor & Item No. & $\begin{array}{c}\text { China } \\
\text { Factor Loading }\end{array}$ & $\begin{array}{c}\text { Korea } \\
\text { Factor Loading }\end{array}$ \\
& & .794 & .794 \\
Product Diagnosticity & Item 1 & .673 & .756 \\
& Item 2 & .816 & .746 \\
\hline Informativeness & Item 3 & .833 & .863 \\
& Item 4 & .833 & .863 \\
Trust & Item 5 & .824 & .859 \\
& Item 6 & .877 & .841 \\
\hline Perceived Information & Item 7 & .887 & .725 \\
Asymmetry & Item 8 & .909 & .861 \\
\hline \multirow{2}{*}{ Fears of Seller } & Item 9 & .909 & .861 \\
Opportunism & Item 10 & .814 & .858 \\
& Item 11 & .848 & .816 \\
\hline Perceived Uncertainty & Item 12 & .724 & .787 \\
(Domestic) & Item 13 & .920 & .880 \\
\hline Perceived Uncertainty & Item 14 & .920 & .899 \\
(Imported) & Item 15 & .948 & .880 \\
\hline
\end{tabular}




\begin{tabular}{lccc}
\hline Factor & Item No. & $\begin{array}{c}\text { China } \\
\text { Factor Loading }\end{array}$ & $\begin{array}{c}\text { Korea } \\
\text { Factor Loading }\end{array}$ \\
\hline \multirow{3}{*}{ Purchase Intention } & Item 18 & .872 & .886 \\
(Domestic) & Item 19 & .870 & .886 \\
& Item 20 & .658 & .845 \\
& Item 21 & .301 & .873 \\
\hline \multirow{3}{*}{ Purchase Intention } & Item 22 & .892 & .838 \\
(Imported) & Item 23 & .883 & .801 \\
& Item 24 & .737 & .415 \\
& Item 25 & .424 & .505 \\
\hline
\end{tabular}

\section{STRUCTURAL PATHS AND HYPOTHESES TESTS}

The structural relationships are tested with the proposed model (Table 7 and 8), and the mixed results came out for four models.

Table 7 - Comparative Analysis for Domestic and Imported Products: China

\begin{tabular}{|c|c|c|c|c|c|c|}
\hline \multirow{2}{*}{\multicolumn{3}{|c|}{ Variable Name }} & \multicolumn{2}{|c|}{ Domestic } & \multicolumn{2}{|c|}{ Imported } \\
\hline & & & Estimate & $\mathbf{P}$ & Estimate & $\mathbf{P}$ \\
\hline Product Diagnosticity & $\rightarrow$ & $\begin{array}{l}\text { Perceived } \\
\text { Information } \\
\text { Asymmetry }\end{array}$ & .154 & .252 & .107 & .442 \\
\hline Informativeness & $\rightarrow$ & $\begin{array}{l}\text { Perceived } \\
\text { Information } \\
\text { Asymmetry }\end{array}$ & .791 & $* * *$ & .947 & $* * *$ \\
\hline Trust & $\rightarrow$ & $\begin{array}{l}\text { Perceived } \\
\text { Information } \\
\text { Asymmetry }\end{array}$ & .065 & .549 & .013 & .911 \\
\hline Product Diagnosticity & $\rightarrow$ & $\begin{array}{l}\text { Fears of Seller } \\
\text { Opportunism }\end{array}$ & .214 & .078 & .140 & .169 \\
\hline Informativeness & $\rightarrow$ & $\begin{array}{l}\text { Fears of Seller } \\
\text { Opportunism }\end{array}$ & .473 & .012 & .753 & $* * *$ \\
\hline Trust & $\rightarrow$ & $\begin{array}{l}\text { Fears of Seller } \\
\text { Opportunism }\end{array}$ & .212 & .030 & .099 & .437 \\
\hline $\begin{array}{l}\text { Perceived Information } \\
\text { Asymmetry }\end{array}$ & $\rightarrow$ & $\begin{array}{l}\text { Perceived } \\
\text { Uncertainty }\end{array}$ & .178 & .020 & .105 & .378 \\
\hline $\begin{array}{l}\text { Fears of Seller } \\
\text { Opportunism }\end{array}$ & & $\begin{array}{l}\text { Perceived } \\
\text { Uncertainty }\end{array}$ & .846 & $* * *$ & .792 & $* * *$ \\
\hline Perceived Uncertainty & $\rightarrow$ & Purchase Intention & .716 & $* * *$ & .511 & $* * *$ \\
\hline $\begin{array}{l}\text { Domestic: } \mathrm{RMR}=.053 \\
\text { Imported: } \mathrm{RMR}=.060\end{array}$ & & $\begin{array}{l}924, \mathrm{CFI}=.954, \mathrm{R} \\
922, \mathrm{CFI}=. .953, \mathrm{~F}\end{array}$ & $\begin{array}{l}\mathrm{SEA}=.05 \\
\mathrm{SEA}=.05\end{array}$ & $\begin{array}{l}\mathrm{P}<0 \\
\mathrm{P}<0 .\end{array}$ & $\begin{array}{l}<<0.05, \\
<0.05, *\end{array}$ & $\begin{array}{l}<0.01 \\
0.01\end{array}$ \\
\hline
\end{tabular}


Table 8 - Comparative Analysis for Domestic and Imported Products: Korea

\begin{tabular}{|c|c|c|c|c|c|c|}
\hline \multirow{2}{*}{\multicolumn{3}{|c|}{ Variable Name }} & \multicolumn{2}{|c|}{ Domestic } & \multicolumn{2}{|c|}{ Imported } \\
\hline & & & Estimate & $\mathbf{P}$ & Estimate & $\mathbf{P}$ \\
\hline $\begin{array}{l}\text { Product } \\
\text { Diagnosticity }\end{array}$ & $\rightarrow$ & $\begin{array}{l}\text { Perceived } \\
\text { Information } \\
\text { Asymmetry }\end{array}$ & .274 & .310 & .271 & .380 \\
\hline Informativeness & $\rightarrow$ & $\begin{array}{l}\text { Perceived } \\
\text { Information } \\
\text { Asymmetry }\end{array}$ & .470 & .009 & .538 & .046 \\
\hline Trust & $\rightarrow$ & $\begin{array}{l}\text { Perceived } \\
\text { Information } \\
\text { Asymmetry }\end{array}$ & .249 & .231 & .187 & .183 \\
\hline $\begin{array}{l}\text { Product } \\
\text { Diagnosticity }\end{array}$ & $\rightarrow$ & $\begin{array}{l}\text { Fears of Seller } \\
\text { Opportunism }\end{array}$ & .452 & .004 & 1.023 & .009 \\
\hline Informativeness & $\rightarrow$ & $\begin{array}{l}\text { Fears of Seller } \\
\text { Opportunism }\end{array}$ & -.302 & .109 & -.542 & .080 \\
\hline Trust & $\rightarrow$ & $\begin{array}{l}\text { Fears of Seller } \\
\text { Opportunism }\end{array}$ & .762 & .004 & .438 & .009 \\
\hline $\begin{array}{l}\text { Perceived } \\
\text { Information } \\
\text { Asymmetry }\end{array}$ & $\rightarrow$ & $\begin{array}{l}\text { Perceived } \\
\text { Uncertainty }\end{array}$ & .438 & $* * *$ & .111 & .404 \\
\hline $\begin{array}{l}\text { Fears of Seller } \\
\text { Opportunism }\end{array}$ & & $\begin{array}{l}\text { Perceived } \\
\text { Uncertainty }\end{array}$ & .578 & $* * *$ & .608 & $* * *$ \\
\hline $\begin{array}{l}\text { Perceived } \\
\text { Uncertainty }\end{array}$ & & Purchase Intention & .822 & $* * *$ & .568 & $* * *$ \\
\hline $\begin{array}{l}\text { Domestic: } \\
\text { Imported: }\end{array}$ & 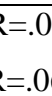 & $\begin{array}{l}\text {, } \mathrm{GFI}=.894, \mathrm{CFI}= \\
\mathrm{GFI}=.889, \mathrm{CFI}=\end{array}$ & $\begin{array}{l}\text { RMSEA } \\
\text { RMSEA }\end{array}$ & $\begin{array}{l}\text { 67, } \mathrm{P} \\
65, \mathrm{P}\end{array}$ & $\begin{array}{l}05, * * *<0 \\
05, * * *<0 .\end{array}$ & \\
\hline
\end{tabular}

\section{Hypotheses of the China Domestic Model \& the China Import Model}

Hypothesis 1a states that product diagnosticity mitigates a buyer's perceived information asymmetry, while Hypothesis $1 \mathrm{~b}$ states that Product diagnosticity mitigates a buyer's fears of seller opportunism. Hypothesis 1a was not supported both in the China Domestic Model and the China Import Model. Hypothesis 1b, on the other hand, was supported in the China Domestic Model.

Hypothesis 2a states informativeness mitigates a buyer's perceived information asymmetry, and Hypothesis $2 \mathrm{~b}$ states informativeness mitigates a buyer's fears of seller opportunism. These two hypotheses were supported in both Chinese models.

Hypothesis 3a states that trust mitigates a buyer's perceived information asymmetry, and Hypothesis 3b says that trust mitigates a buyer's fears of seller 
opportunism. Hypothesis 3a was rejected in both two models, while Hypothesis $3 \mathrm{~b}$ was supported only in the China Import Model.

Hypothesis 4 says that perceived information asymmetry positively influences a buyer's perceived uncertainty. This hypothesis was supported only in the China Import model. Hypothesis 5 says that fears of seller opportunism positively influence a buyer's perceived uncertainty, which was supported both models. Hypothesis 6 says that a buyer's perceived uncertainty negatively influences his/her purchase intention, which was strongly supported in both models.

\section{Hypotheses of the Korea Domestic Model \& the Korea Import Model}

Hypothesis 1a was not supported both in the Korea Domestic Model and the Korea Import Model. Hypothesis 1b, on the other hand, was supported both in the Korea Domestic Model and the Korea Import Model. Both Hypothesis 2a and $2 \mathrm{~b}$ were supported in both models. Hypothesis $3 \mathrm{a}$ was rejected in both models and $3 \mathrm{~b}$ was supported in the two models. Hypothesis 4 was supported only in the Korea Domestic model. Hypothesis 5 \& 6 were supported in both models.

The goodness-of-fit (GFI), root-mean-square error of approximation (RMSEA), and comparative fit index (CFI) were; .924, .051 and .954 for the China Domestic Model: .922,.052 and 0.953 for the China Import Model (Table 9). The goodness-of-fit (GFI), root-mean-square error of approximation (RMSEA), and comparative fit index (CFI) were; .894,.067 and .926 for the Korea Domestic Model : .889, .065 and .923 for the Korea Import Model (Table 9). These measures indicate that all four models show an adequate fit.

Table 9 - Hypotheses Testing of the Proposed Theoretical Model

\begin{tabular}{ll}
\hline Hypothesis 1a & Product diagnosticity mitigate a buyer's perceived information asymmetry. \\
Hypothesis 1b & Product diagnosticity mitigates a buyer's fears of seller opportunism. \\
Hypothesis 2a & Informativeness mitigates a buyer's perceived information asymmetry. \\
Hypothesis 2b & $\begin{array}{l}\text { Informativeness mitigates a buyer's fears of seller opportunism } \\
\text { Hypothesis 3a }\end{array}$ \\
Trust mitigates a buyer's perceived information asymmetry. \\
Hypothesis 3b & $\begin{array}{l}\text { Trust mitigates a buyer's fears of seller opportunism } \\
\text { Hypothesis 4 }\end{array}$ \\
$\begin{array}{l}\text { Perceived information asymmetry positively influences a buyer's perceived } \\
\text { uncertainty. }\end{array}$ \\
Hypothesis 5 & $\begin{array}{l}\text { Fears of seller opportunism positively influence a buyer's perceived } \\
\text { uncertainty. }\end{array}$ \\
Hypothesis 6 & $\begin{array}{l}\text { A buyer's perceived uncertainty negatively influences his/her purchase } \\
\text { intention. }\end{array}$
\end{tabular}




\section{DISCUSSION AND CONCLUSION}

The paper validates a model which approximates a relationship between perceived uncertainty of consumers and two antecedents \& three mitigators which explain the value of Food Traceability System (FTS). The proposed model was drawn from Pavlou, Liang and Xue (2007) study which applied the principal-agent perspectives, and this study contributes to current literature by improving understanding of structure of perceived uncertainty of a food product with credence good with this model. In addition, the study assesses the value and effects of FTS in reducing perceived uncertainty of beef from various origins and suggests important implications for stakeholders in beef sector regarding feasibility and marketability of FTS.

This study has several key findings that are validated in two distinct empirical cases (i.e. countries) with two different products (i.e. domestic products vs. import products). First, Fears of seller opportunism were found to have statistically significant and strong effect on Perceived Uncertainty both in Korea \& China Domestic and Import models. On the other hand, Perceived Information Asymmetry was found to be statistically significant only for Domestic Model both in China and Korea, and its impact was much smaller than Fears of seller opportunism. Two, Perceived Uncertainty was found to have significant impact on Purchase Intention in all four models. The effect of Perceived Uncertainty was found to be greater in the Domestic model in China and Korea. Third, among three uncertainty mitigators, Informativeness was found to have the largest impact on the two antecedents of Perceived Uncertainty (i.e. Fears of seller opportunism \& Perceived Information Asymmetry) in the China Domestic \& China Import Models. More specifically, Informativeness had larger impact on Perceived Information Asymmetry. In Korean case, significantly different outcomes were found out. Product Diagnosticity \& Trust had significant effects on Fears of Seller Opportunism, while Informativeness had impacts on both Fears of seller opportunism \& Perceived Information Asymmetry.

Both in China and South Korea, uncertainty perceptions due to Fears of Seller Opportunism appear to negatively affect consumers' beef purchase intention. Its impact was much greater than the other antecedent, Perceived Information Asymmetry. However, results suggest different approach in dealing with this challenge in China and South Korea. Chinese consumers perceive Informativeness to be a major factor that could improve their perceived uncertainty situation. "quick and easy access to large volume of information" and "being able to learn a lot from FTS" are found to be of value for Chinese consumers in purchasing traceable beef products. On the other hand, Korean consumers were found to value different aspect of FTS in reducing their Fears of Seller Opportunism. For domestic beef choice, Trust was found to have the largest effect on Fears of Seller Opportunism, while Product Diagnosticity had the largest effect on Fears of Seller Opportunism for import beef choice. In other words, Korean consumers consider the FTS to "provide objective information on domestic beef products sufficiently" \& "information on FTS is trustworthy" for 
the FTS of domestic beef. In term of import beef choice, they expect FTS "to help them evaluate their choice" \& "make it much easier to purchase import beef".

The proposed model confirms that Perceived Uncertainty of consumers function as a critical impediment in consumes' beef purchase decision, and Fears of Seller Opportunism \& Perceived Information Asymmetry are two major sources underlying the Perceived Uncertainty. Cross-country validation of the proposed model enables elicitation of differentiated implications for China and South Korea. Findings evidently reflect the current market circumstance regarding consumers' concerns and Perceived Uncertainty towards import food products for their credence nature. Different aspects of FTS were found to have mediating role in reducing Perceived Uncertainty in China and South Korea.

Table 10 - Preferred Country of Origin for Beef Purchase in China \& Korea

\begin{tabular}{ccc}
\hline Country & China & Korea \\
\hline Home Country & 31.1 & 62.7 \\
USA & 15.1 & 2.7 \\
Australia & 23.7 & 28.0 \\
Canada & 3.0 & 1.8 \\
New Zealand & 27.1 & 4.9 \\
\hline
\end{tabular}

This may be due to different attitude of consumers in China and Korea toward their domestic beef products (Table 10). Korean consumers had distinctly higher rate of preference $(62.6 \%)$ for domestic origin for beef choice compared to Chinese consumers $(31.1 \%)$. Consumers' preference for other country origins also showed mixed results. Beef products from Australia (23.7\%) and New Zealand $(27.1 \%)$ were similarly preferred by Chinese consumers, followed by the U.S. origin (15.1\%). In contrast, Korean consumers identified Australian (28\%) origin as a preferred import beef, while other origins showed considerably weak preference by Korean consumers. Due to this fundamentally different preference structure in China and Korea, consumers' Perceived Uncertainty may be mitigated by different factors. Informativeness was found to be the most effective aspects of FTS improving Chinese consumers' Perceived Uncertainty for both Domestic and Import beef choices. For Korean consumers, Product Diagnosticity was the most valuable aspect of FTS for Import beef, while Trust was the most influential factor for Domestic beef choice. Marketers and policy makers should recognize the relative effectiveness of each uncertainty mitigators in communicating the product information with consumers. It is important to note that different aspects of FTS should be emphasized in different countries and also for different type of products (i.e. domestic vs. import). 


\section{ACKNOWLEDGMENTS}

The research reported is funded by the Social Science Korea (SSK) Research Grant of the National Research Foundation of Korea (NRF), and the author would like to thank the NRFK for supporting our research project (NRF2013S1A3A2052995).

\section{REFERENCES}

Aaker, J.L. 2000. Accessibility or Diagnosticity? Disentangling the Influence of Culture on Persuasion Processes and Attitudes. Journal of Consumer Research, 26(4) (March), pp.340-357.

Aboulnasr, K., 2006. Country of Origin Effects: The Role of Information Diagnosticity, Information Typicality and Involvement. Marketing Management Journal, 16(1), pp.1-18.

Chiles, T.H., and McMackin, J.F., 1996. Integrating variable risk preferences, trust, and transaction cost economics. The Academy of Management Review, 21(1), pp.73-99.

Choe, Y.C., Park J.W., Chung, M. and Moon, J.H., 2009. Effect of the food traceability system for building trust: Price Premium and buying behavior. Information Systems Frontiers, 11(2), pp.167-179.

Ducoffe, R.H., 1996. How consumers assess the value of advertising. Journal of Current Issues and Research in Advertising, 17(1), pp.1-18.

Eisenhardt, K., 1989. Agency Theory: An Assessment and Review, Academy of Management Review, 14(1), pp.57-74.

Garretson, J.A. and Burton, S., 2000. Effects of Nutrition Facts Panel Values, Nutrition Claims, and Health Claims on Consumer Attitudes, Perceptions of Disease-Related Risks, and Trust. Journal of Public Policy and Marketing, 19(2), pp.213-227.

GS1, 2009. Case Study: Food Traceability, GS1 Traceability Implementation between China and France. GS1 AISBL.

Gurhan-Canli, Z. and Maheswaran, D., 2000. Determinants of Country-OfOrigin Evaluations, Journal of Consumer Research 27(1), pp.96-108.

Häubl, G., 1996. A Cross-National Investigation of the Effects of Country of Origin and Brand Name on the Evaluation of a New Car. International Marketing Review, 13(5), pp.76-97.

Hoch, Stephen J. and Young-Won Ha.1986. Consumer Learning: Advertising and the Ambiguity of Product Experience. Journal of Consumer Research, 13(2), pp. 221-233. 
Hong, S.T. and Wyer, R.S. Jr., 1989. Effects of Country of Origin and Product Attribute Information on Product Evaluation: An Information Processing Perspective. Journal of Consumer Research, 16(2), pp.175-187.

Jansen-Vullers, M.H., Van Dorp, C.A. and Beulens, A.J.M., 2003. Managing traceability information in manufacture. International Journal of Information Management, 23(5), pp.395-413.

Jensen, M. and Meckling, W.H., 1972. The Theory of the Firm: Managerial Behavior, Agency Costs and Ownership Structure. Journal of Financial Economics, 3(4), pp.305-360.

Jiang, Z. and Benbasat, I., 2004. Virtual Product Experience: Effects of Visual and Functional Control of Products on Perceived Diagnosticity and Flow in Electronic Shopping. Journal of Management Information Systems, 21(3), pp.111 -147 .

Kahneman, D. and Tversky, A., 1979. Prospect theory: an analysis of decision under risk. Econometrica, 47(2), pp.263-292.

Kempf, D.S. and Smith, R.E., 1998. Consumer Processing of Product Trial and the Influence of Prior Knowledge: A Structural Modeling Approach. Journal of Marketing Research, 35(3), pp.325 -337.

Kim, R., Chao, Y. and Zhang, Q., (in press) Comparative Analysis of Food Risk Management Quality (FRMQ) of the Public vs. the Private Sectors: Chinese Consumers' perspectives. International Journal of Economics \& Management in Review

Maheswaran, D., 1994. Country of Origin as a Stereotype: Effects of Consumer Expertise and Attribute Strength on Product Evaluations. Journal of Consumer Research, 21(2), pp.354-365.

Mayer, R.C., Davis, J.H. and Schoorman, F.D., 1995. An Integrative model of Organizational Trust. Academy of Management Review, 20(3), pp.709-734.

Meyer, H., 1999. When the cause is just. Journal of Business Strategy, 20(6), pp.27-31.

Milgrom, P. and Roberts, J., 1992. Economics, organization and management. New Jersey, NJ: Prentice Hall.

Mishra, D.P., Heide, J.B. and Cort, S.G, 1998. Information Asymmetry and Levels of Agency Relationships. Journal of Marketing Research, 35(3), pp.277295.

Nagashima, A., 1970. A Comparison of Japanese and U.S. Attitudes Toward Foreign Products. Journal of Marketing, 34(1), pp.68 -74.

Pavlou, P.A. and Fygenson, M., 2006. Understanding and predicting electronic comer adoption: an extension of the theory of planned behavior. MIS Quarterly, 30(1), pp.115-143. 
Pavlou, P.A. and Gefen, D., 2004. Building effective online marketplaces with institution-based trust. Information Systems Research, 15(1), pp.37-59.

Pavlou, P.A., Liang, H. and Xue, Y., 2007. Understanding and mitigating uncertainty in online environments: a principal-agent perspective. MIS Quarterly, 31(1), pp.105-136.

Rousseau, D.M., Sitkin, S.B., Burt, R.S. and Camerer, C., 1998. Not so different after all: A cross-discipline view of trust. Academy of Management Review, 23(3), pp.393-404.

Swan, J.E. and Nolan, J.J., 1985. Gaining customer trust: a conceptual guide for the salesperson. Journal of Personal Selling and Sales Management, 5(2), pp.3948.

Wang, Z.G., Weng, Y.Z., Yang, Z.G. and Zheng, F.T., 2016. The effectiveness of adopting HACCP system certification in food industry: From the questionnaire of 482 food manufacturing enterprises in China. China Soft Science, 2006(9), pp.69-76.

\section{ABOUT THE AUTHORS}

D. H. Yoon is a research fellow at the KISE research institute, Hanyang University, Korea, and specialized in international marketing and international business strategy. He has published several research papers in cross country analysis of consumers in Asia, including Korea and China.

Q. Zhang is a professor in Risk Management, China Academy of Agricultural Science (CAAS), China. He is also the managing director of the Agricultural Information Institute (AII) at CAAS, and Secretary General of the Agricultural Sci-technology Information Society. His research focuses on agricultural risk management, rural finance \& marketing of agricultural commodity. He has published more than 90 papers in academic journal and completed more than 50 projects which are consigned by Chinese government and international fund.

R. B. Kim is a professor in international business, international marketing at School of Business, Hanyang University, Korea. She is also the executive director of KISE research institute, and has published over 50 publications in peer-reviewed international journals. Her research focuses on international consumer marketing studies, international business strategy, global branding strategy etc. 